\title{
DEKOMPOSISI TRADED SPREAD SAHAM DI BURSA EFEK INDONESIA: ORDER PROCESSING COST, INVENTORY HOLDING COST, DAN ADVERSE SELECTION COST
}

\author{
Oleh: \\ Dr. Donalson Silalahi
}

\begin{abstract}
Stock market performance can be viewed from various aspects. One of this aspect is the amount of traded spread. The greater of traded spread can be caused by a lack of trading system and disclosure. Therefore, the decomposition of traded spread is important for the study.

This research was conducted to develop a model of traded spread and prove that: the order processing cost, inventory holding cost, and adverse selection cost are the component of traded spread.

To achieve these objectives, the stock price and order flow observed during the years 2007 - 2008 and using the purposive sampling as the sampling technique. Samples were observed at 1.782 and using trade indicators to determine whether the transactions undertaken based on the ask price or bid price. The data were analyzed using the multiple regression.

The research indicated that: First, the model of traded spread can be used to explain the decomposition of traded spread. Second, the contribution of order processing cost is 29 per cent, the contribution of inventory holding cost is 68 per cent, and the contribution of adverse selection cost is 3 percent. Third, the contribution of adverse selection cost is relatively low when compared with the contribution of real spread. Furthermore, the results of this study can be used to determine the policies in reducing of traded spread.
\end{abstract}

Keywords: Traded Spread, Order Processing Cost, Inventory Holding Cost, Adverse Selection Cost.

\section{PENDAHULUAN}

Kinerja pasar saham dapat dilihat dari berbagai aspek. Salah satu di antaranya adalah melalui besaran bid ask spread, atau spread. Spread merupakan perbedaan antara harga kuotasi beli dan harga kuotasi jual dalam mekanisme perdagangan saham. Oleh karenanya, konsep spread sering dipergunakan untuk menjelaskan tingkat likuiditas atau biaya transaksi. Spread yang semakin besar mengindikasikan rendahnya likuiditas pasar atau mahalnya biaya transaksi dalam mekanisme perdagangan saham. Sebaliknya, spread yang semakin rendah mengindikasikan bahwa pasar saham semakin likuid. Artinya, biaya transaksi untuk melaksanakan aktivitas perdagangan saham semakin murah. Dengan demikian, besaran spread menjadi fokus perhatian traders dan investor dalam melaksanakan aktivitas perdagangan serta otoritas bursa dalam meningkatkan kinerja pasar saham.

Menurut Stoll (2000), spread yang semakin besar dapat disebabkan oleh mekanisme perdagangan yang kurang baik dan tingkat disclosure yang lemah. Sistem perdagangan yang kurang baik dicerminkan melalui dominasi kontribusi real friction terhadap spread. Sebaliknya, disclosure yang lemah dicerminkan melalui dominasi kontribusi information friction terhadap spread. Oleh karenanya, dekomposisi spread dalam mekanisme perdagangan menjadi semakin penting diteliti untuk menentukan kebijakan dalam rangka meningkatkan kinerja pasar saham.

Dalam melaksanakan aktivitas perdagangan saham di Bursa Efek Indonesia, investor selalu mempergunakan jasa para perantara yang menjadi anggota bursa. Para perantara tersebut melaksanakan amanah investor dengan prinsip limit order, yaitu, pesanan dilaksanakan para perantara sampai dengan batas harga yang ditetapkan oleh nasabahnya. Sebagai perantara 
yang memiliki akses langsung ke Bursa Efek Indonesia, maka pengelola bursa membebankan biaya sebesar $\quad$ Rp 2.000 .000 per bulan kepada perantara. Selain biaya tersebut, masih terdapat jenis biaya lain yang menjadi beban bagi masing-masing perantara, seperti: biaya sewa kantor, pajak maupun gaji yang dibayarkan kepada traders. Oleh karenanya, untuk mempertahankan eksistensinya, para perantara membebankan biaya tersebut kepada nasabahnya sehingga berdampak terhadap order processing cost.

Sebagai perantara atau market maker, perantara juga melakukan order beli dan order jual untuk memenuhi kebutuhan portofolionya. Oleh karenanya, perantara berusaha untuk meningkatkan probabilitas bahwa posisi persediaannya berubah menjadi posisi persediaan sebagaimana diharapkan. Untuk memenuhi kebutuhan rebalancing portofolio tersebut, maka pihak perantara atau market maker merevisi harga kuotasi beli dan jual yang pada akhirnya berdampak terhadap inventory holding cost.

Lebih lanjut, dalam melaksanakan aktivitas order beli dan order jual, para perantara dimungkinkan berhadapan dengan informed traders, yaitu: traders yang memiliki informasi private tentang nilai suatu saham. Dalam kondisi seperti ini, perantara akan mengalami kerugian sehingga merevisi harga kuotasi beli dan jual sebagai kompensasi atas kerugian tersebut. Semakin sering perantara berhadapan dengan agents yang memiliki informasi private tentang nilai suatu saham, maka perantara semakin sering merevisi harga kuotasi beli dan jual yang pada akhirnya berdampak terhadap adverse selection cost.

Berdasarkan paparan tersebut, maka dekomposisi spread dalam mekanisme perdagangan saham terdiri dari tiga komponen, yaitu: komponen order processing cost, inventory holding cost, dan adverse selection cost. Dengan mengetahui besaran kontribusi masing-masing komponen traded spread tersebut, maka pihak regulator dapat membuat kebijakan konkrit dalam meningkatkan kinerja pasar saham di Bursa Efek Indonesia. Oleh karenanya, dekomposisi traded spread semakin penting diteliti untuk meningkatkan kinerja pasar saham, sebab kebijakan yang dilakukan tergantung dari struktur komponen pembentuk traded spread.

Dewasa ini, berbagai model telah dikembangkan untuk mengestimasi spread dan komponennya, di antaranya: Roll (1984); Stoll (1989) dan George et al. (1991). Dalam mengestimasi spread dan komponennya, dipergunakan kovarians harga transaksi maupun harga kuotasi. Lebih lanjut dikemukakan bahwa model dibangun berdasarkan suatu asumsi bahwa pasar modal adalah efisien. Oleh karenanya, model tersebut kurang tepat bila diimplementasikan langsung di pasar modal yang sedang berkembang.

Pasar Modal Indonesia merupakan pasar modal yang sedang berkembang (Fuss: 2002). Oleh karenanya, untuk mengestimasi traded spread dan dekomposisinya atas komponen order processing cost, inventory holding cost, dan adverse selection cost dibangun suatu model indikator. Model indikator dipergunakan disebabkan model tersebut lebih sesuai untuk pasar modal yang sedang berkembang sebagaimana dikemukakan oleh Hanousek dan Podpiera (2002). Di samping itu, model indikator juga dapat dipergunakan untuk mengidentifikasi apakah transaksi saham dilakukan atas inisyatif buyer atau seller. Lebih lanjut, model indikator juga sangat sesuai diimplementasikan di Bursa Efek Indonesia terutama jika mempergunakan data yang bersumber dari Indonesian Capital market Directory.

Berdasarkan paparan tersebut di atas, maka penelitian ini dimaksudkan untuk: Pertama, membangun model traded spread saham di Bursa Efek Indonesia, Kedua, menentukan dekomposisi traded spread saham di Bursa Efek Indonesia, dan Ketiga, mendapatkan bukti empiris bahwa order processing cost, inventory holding cost, dan adverse selection cost merupakan komponen traded spread. 


\section{MODEL TRADED SPREAD SAHAM}

Secara teoritis, traded spread terdiri dari tiga komponen, yaitu: order processing costs, Inventory holding costs, dan adverse selection costs. Dalam menentukan dekomposisi traded spread, dipergunakan model indikator sebagaimana dikemukakan oleh Huang dan Stoll (1997). Dalam membangun model, dipergunakan beberapa variabel sebagai berikut: $V_{t}$ merupakan nilai fundamental atau true value sekuritas pada periode $\mathrm{t}, \mathrm{M}_{\mathrm{t}}$ merupakan rata-rata harga kuotasi pada periode $t, P_{t}$ merupakan harga transaksi pada periode $t, Q_{t}$ merupakan order flow, $S$ merupakan traded spread yang bernilai konstan, a merupakan persentase traded spread sebagai komponen adverse selection cost, $\beta$ merupakan persentase traded spread sebagai komponen inventory holding cost, dan $\lambda$ merupakan persentase traded spread sebagai komponen adverse selection dan inventory holding costs.

Dalam membangun model traded spread dan komponennya, dipergunakan beberapa asumsi. Pertama, diasumsikan bahwa nilai fundamental atau true value sekuritas tergantung dari arah order flow dan informasi publik sebagaimana ditunjukkan pada model berikut:

$$
\mathrm{V}_{\mathrm{t}}=\mathrm{V}_{\mathrm{t}-1}+\mathrm{aS} / 2 \mathrm{Q}_{\mathrm{t}-1}+\varepsilon_{\mathrm{t}}
$$

Berdasarkan persamaan (1) dapat dikemukakan bahwa nilai fundamental atau true value sekuritas tergantung dari informasi private tentang order flow di masa lalu dengan nilai sebesar $\mathrm{a}(S / 2) Q_{\mathrm{t}-1}$ dan komponen informasi publik, $\varepsilon_{\mathrm{t}}$. Persamaan (1) tersebut tidak dapat diamati disebabkan dalam model masih terdapat nilai fundamental atau true value. Kedua, diasumsikan bahwa setiap order flow mempengaruhi posisi persediaan market maker. Oleh karenanya, ratarata harga kuotasi, $\mathrm{M}_{\mathrm{t}}$, sekuritas adalah sebagai berikut :

$$
\mathrm{M}_{\mathrm{t}}=\mathrm{V}_{\mathrm{t}}+\sum_{i=0}^{t-1} \beta \frac{S}{2} \mathrm{Q}_{\mathrm{i}}
$$

Persamaan (2) tersebut menunjukkan bahwa nilai $\beta$ menggambarkan proporsi inventory holding cost terhadap spread. Oleh karenanya, jika inventory holding cost tidak ada, maka $_{\mathrm{t}}=$ $\mathrm{V}_{\text {t. }}$ Persamaan (2) juga tidak dapat diamati disebabkan dalam model masih terdapat nilai fundamental atau true value. Ketiga, diasumsikan bahwa spread konstan sehingga deviasi spread $\left(P_{t}-M_{t}\right)$ yang diamati adalah sebagai berikut:

$$
\mathrm{P}_{\mathrm{t}}-\mathrm{M}_{\mathrm{t}}=\mathrm{S} / 2 \mathrm{Q}_{\mathrm{t}}+\eta_{\mathrm{t}}
$$

Dengan mengkombinasikan persamaan (1), (2), dan (3) serta menggunakan first differences, maka diperoleh persamaan sebagai berikut:

$$
\Delta \mathrm{P}_{\mathrm{t}}=\mathrm{S} / 2\left(\mathrm{Q}_{\mathrm{t}}-\mathrm{Q}_{\mathrm{t}-1}\right)+\lambda \mathrm{S} / 2 \mathrm{Q}_{\mathrm{t}-1}+\mathrm{e}_{\mathrm{t}}
$$

Berdasarkan persamaan (4) dapat dikemukakan bahwa perbedaan indikator order flow periode $\mathrm{t}$ dan periode $\mathrm{t}-1$ dengan parameter S/ 2 menggambarkan traded spread. Order flow pada periode $\mathrm{t}$ - 1 dengan parameter $\lambda$ menggambarkan jumlah komponen inventory holding cost dan adverse selection costs atau $\lambda=\alpha+\beta$. Oleh karenanya, order processing cost dapat ditentukan dengan mempergunakan formula 1 - $\lambda$, sebab traded spread merupakan penjumlahan antara order processing cost dengan inventory holding cost dan adverse selection cost.

Persaman (4) tersebut hanya dapat dipergunakan untuk mengestimasi traded spread dan order processing cost dan belum memisahkan komponen inventory holding cost dan adverse selection cost. Oleh karenanya, perlu diamati hubungan antar order flow dalam rangka memisahkan komponen inventory holding cost dengan komponen adverse selection cost. Menurut Huang dan Stoll (1997) bahwa variabel indikator perdagangan pada periode $t-1$, tergantung dari indikator perdagangan pada periode $t-2$, yang dimodelkan sebagai berikut:

$$
\mathrm{E}\left(\mathrm{Q}_{\mathrm{t}-1} / \mathrm{Q}_{\mathrm{t}-2}\right)=(1-2 \pi) \mathrm{Q}_{\mathrm{t}-2}
$$


dimana: $\pi$ merupakan probabilitas trade reversal, artinya kemungkinan arah perdagangan pada periode perdagangan berikutnya memiliki arah yang berlawanan dengan arah perdagangan pada periode sebelumnya. Jika diasumsikan bahwa pasar mengetahui kondisi persamaan (5), maka perubahan nilai fundamental atau true value sekuritas, $\Delta \mathrm{V}_{\mathrm{t}}$, adalah sebagai berikut:

$\Delta \mathrm{V}_{\mathrm{t}}=\mathrm{aS} / 2 \mathrm{Q}_{\mathrm{t}-1}-\mathrm{aS} / 2(1-2 \pi) \mathrm{Q}_{\mathrm{t}-2}+\varepsilon_{\mathrm{t}}$.

Dengan mengkombinasikan persamaan (6) terhadap persamaan (3), maka diperoleh perubahan harga kuotasi, $\Delta \mathrm{M}_{\mathrm{t}}$, sebagai berikut:

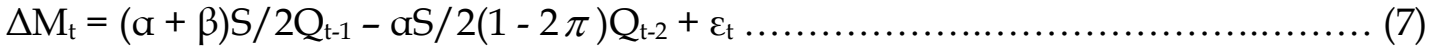

Selanjutnya dengan menambahkan suatu asumsi bahwa spread konstan sehingga menghasilkan persamaan berikut:

$\Delta \mathrm{P}_{\mathrm{t}}=\mathrm{S} / 2 \mathrm{Q}_{\mathrm{t}}+(\mathrm{a}+\beta-1) \mathrm{S} / 2 \mathrm{Q}_{\mathrm{t}-1}-\mathrm{aS} / 2(1-2 \pi) \mathrm{Q}_{\mathrm{t}-2}+\mathrm{e}_{\mathrm{t}}$

Berdasarkan persamaan-persamaan tersebut di atas, maka dalam mengestimasi traded spread dan komponennya atas komponen order processing cost, inventory holding cost, dan adverse selection cost dipergunakan persamaan (4) dan (8).

\section{METODE PENELITIAN}

Dalam penelitian ini, variabel dependen adalah perubahan harga dari masing-masing saham yang diamati. Perubahan harga ditentukan berdasarkan selisih antara harga penutupan saham pada bulan $t$, dengan harga penutupan saham pada bulan $t-1$. Variabel independen adalah order flow. Order flow yang pertama adalah perbedaan indikator perdagangan saham pada bulan $\mathrm{t}$ dengan indikator perdagangan saham pada bulan $\mathrm{t}-1$. Order flow yang kedua adalah indikator perdagangan saham pada bulan t. Order flow yang ketiga adalah indikator perdagangan saham pada bulan $\mathrm{t}-1$, dan order flow yang keempat adalah indikator perdagangan saham pada bulan $\mathrm{t}-2$.

Dalam menentukan arah order flow, Q, apakah trade berdasarkan ask atau bid price dipergunakan klasifikasi trade yang diusulkan oleh Ellis et al. (2000). Jika harga transaksi, $\mathrm{P}_{\mathrm{t}}>$ $\mathrm{P}_{\mathrm{t}-1}$ maka order flow bernilai 1 berarti transaksi dilakukan berdasarkan ask price, jika harga transaksi, $\mathrm{P}_{\mathrm{t}}<\mathrm{P}_{\mathrm{t}-1}$, maka order flow bernilai - 1 berarti transaksi dilakukan berdasarkan bid price, dan jika $P_{t}=P_{t-1}$ maka $Q_{t}=Q_{t-1}$.

Penelitian dilakukan di Bursa Efek Indonesia dengan periode pengamatan tahun 2007 2008. Sampel ditentukan berdasarkan purposive sampling dengan sample size sebesar 1.782 pengamatan. Semua data tersebut didapatkan dari Indonesian Capital Market Directory Tahun 2008. Dengan demikian data yang dipergunakan adalah data sekunder dengan mempergunakan teknik dokumentasi.

Dalam menentukan traded spread saham dan komponennya atas order processing cost, inventory holding cost, dan adverse selection cost dipergunakan persamaan regresi berganda secara bertahap. Tahap pertama, menentukan traded spread dengan jumlah komponen inventory holding cost dan adverse selection cost. Dalam menentukan traded spread saham dan jumlah komponen inventory holding cost dan adverse selection cost dipergunakan persamaan regresi berikut:

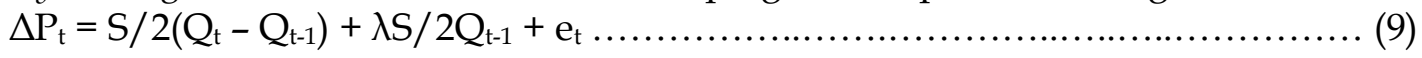

Berdasarkan persamaan regressi tersebut, besaran traded spread ditunjukkan oleh nilai koefisien $\mathrm{S} / 2$. Jumlah komponen inventory holding cost dan adverse selection cost ditunjukkan oleh nilai koefisien $\lambda S / 2$. Berdasarkan hasil estimasi atas komponen inventory holding cost dan adverse selection cost, maka besaran order processing cost dapat ditentukan dengan mempergunakan formula $1-\lambda$. 
Tahap kedua, adalah meregresikan variabel indikator perdagangan saham bulan $\mathrm{t}-2$ dengan variabel indikator perdagangan saham bulan $t-1$ dengan mempergunakan persamaan regresi sebagai berikut:

$$
\mathrm{E}\left(\mathrm{Q}_{\mathrm{t}-1}\right)=(1-2 \pi) \mathrm{Q}_{\mathrm{t}-2}
$$

Koefisien regresi dari persamaan (10) kemudian dipergunakan sebagai input dalam menentukan komponen adverse selection cost.

Tahap ketiga, mengestimasi komponen adverse selection cost dengan mempergunakan persamaan berikut:

$$
\Delta \mathrm{P}_{\mathrm{t}}=\mathrm{S} / 2 \mathrm{Q}_{\mathrm{t}}+(\alpha+\beta-1) \mathrm{S} / 2 \mathrm{Q}_{\mathrm{t}-1}-\mathrm{aS} / 2(1-2 \pi) \mathrm{Q}_{\mathrm{t}-2}+\mathrm{e}_{\mathrm{t}}
$$

Berdasarkan persamaan regresi tersebut, maka besaran adverse selection cost ditunjukkan oleh nilai koefisien aS/2. Berdasarkan hasil estimasi atas komponen adverse selection cost, maka ditentukan besaran inventory holding cost dengan mempergunakan formula $\lambda=\alpha+\beta$.

Tahap keempat, menentukan kontribusi masing-masing komponen order processing cost, inventory holding cost dan adverse selection cost terhadap traded spread dengan mempergunakan formula berikut: $\lambda=\alpha+\beta$. Nilai koefisien $\lambda$ diperoleh dari persamaan (9) dan nilai koefisien $\alpha$ diperoleh dari persamaan (11).

Untuk menentukan ketepatan model dilakukan pengujian terhadap koefisien determinan yang dihasilkan dari persamaan (11), disebabkan persamaan tersebut mengandung semua komponen traded spread. Selanjutnya, untuk memperoleh informasi perkembangan kinerja pasar saham, model juga diimplementasikan berdasarkan pengelompokan data sampel penelitian, yaitu: berdasarkan tahun pengamatan.

\section{HASIL PENELITIAN DAN PEMBAHASAN}

\section{Harga dan Perubahan Harga Saham}

Berdasarkan pengamatan terhadap 1.782 harga saham perusahaan yang terdaftar di Bursa Efek Indonesia selama tahun 2007 - 2008, rata-rata harga saham adalah Rp 64.853 atau harga saham berada dalam kisaran $\operatorname{Rp} 40$ - Rp 129.500. Kondisi ini menggambarkan bahwa harga saham perusahaan-perusahaan yang diamati cukup fluktuatif. Tingkat perubahan harga saham berada dalam kisaran Rp 400. Harga saham yang diamati ada yang menunjukkan peningkatan, penurunan, dan tidak mengalami perubahan. Harga saham yang mengalami perubahan positip sebanyak 1.312 pengamatan sehingga terdapat 1.312 transaksi berdasarkan ask price. Harga saham yang mengalami perubahan negatif sebanyak 332 pengamatan sehingga terdapat 332 transaksi berdasarkan bid price. Selanjutnya, harga saham yang tidak mengalami perubahan sebanyak 138 pengamatan sehingga terdapat 138 transaksi yang tidak jelas apakah perdagangan dilakukan berdasarkan ask price atau bid price. Perubahan harga-harga saham penutupan tersebut ditunjukkan pada Gambar 1 berikut ini.

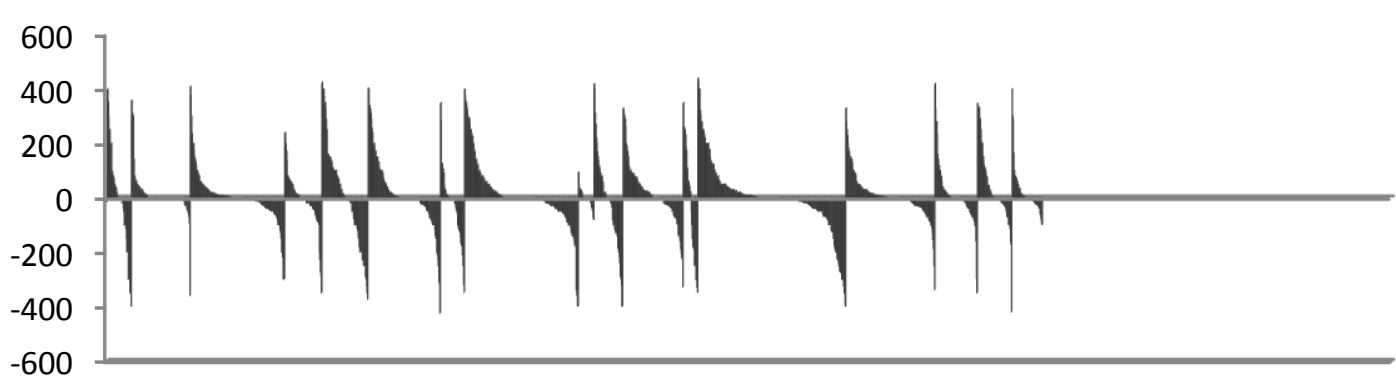


Gambar 1. Fluktuasi Perubahan Harga Saham Penutupan Selama Periode Pengamatan Tahun $2007-2008$.

\section{Hasil Estimasi Dekomposisi Traded Spread}

Dalam mengestimasi dekomposisi traded spread atas komponen order processing cost, inventory holding cost, dan adverse selection cost dilakukan melalui 4 (empat) tahap. Pertama, mengestimasi traded spread saham dan jumlah komponen inventory holding cost dan adverse selection cost. Hasil estimasi traded spread saham dan jumlah komponen inventory holding cost dan adverse selection cost dapat dilihat pada Tabel 1 berikut.

Tabel 1. Rekapitulasi Hasil Penelitian Traded Spread, Jumlah Komponen Inventory Holding Cost dan Adverse Selection Cost

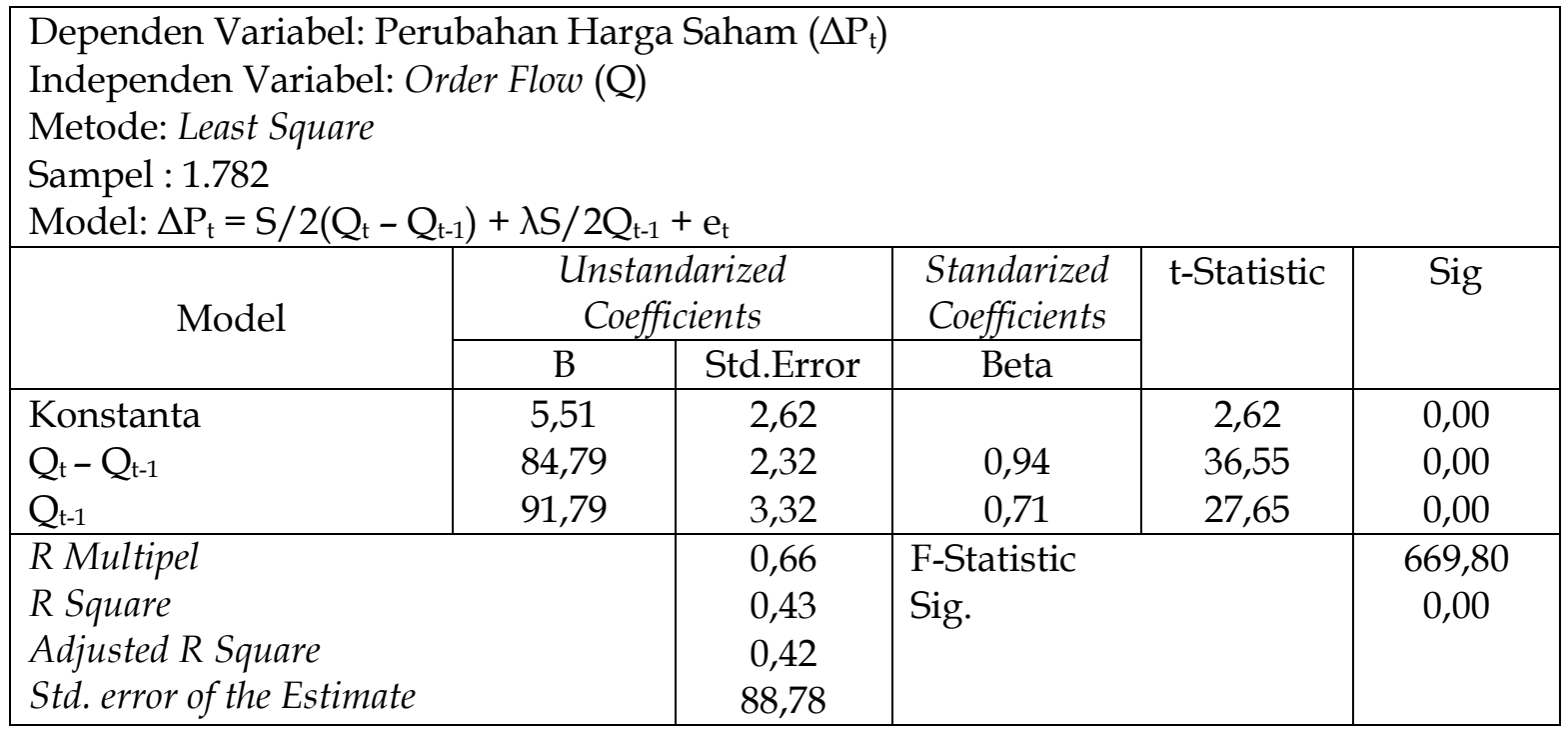

Sumber: Hasil Olahan Data Penelitian dengan Mempergunakan SPSS Version 15.

Berdasarkan Tabel 1 di atas dapat dikemukakan bahwa nilai $R$-Square adalah 43 persen dan signifikan secara statistik dengan nilai F-hitung sebesar 669,8 (probabilitas sebesar 0,00). Selanjutnya, nilai traded spread saham di Bursa Efek Indonesia adalah 0,94 dan signifikan secara statistik dengan nilai t-hitung sebesar 36,55 (probabilitas sebesar 0,00). Koefisien jumlah inventory holding cost dan adverse selection cost sebesar 0,71 dan signifikan secara statistik dengan nilai t-hitung adalah 27,65 (probabilitas sebesar 0,00). Dengan mempergunakan besaran koefisien jumlah inventory holding cost dan adverse selection cost, maka besaran order processing cost ditentukan dengan mempergunakan formula $1-\lambda$. Oleh karenanya, secara rata-rata besaran order processing cost adalah 0,29.

Kedua, menentukan kemungkinan arah order flow pada periode $\mathrm{t}-2$ berlawanan arah dengan arah order flow pada periode $t-1$. Estimasi hubungan antar order flow ditunjukkan pada Tabel 2 berikut.

Tabel 2. Estimasi Hubungan Order Flow

Dependen Variabel: Order Flow periode $\mathrm{t}-1\left(\mathrm{Q}_{\mathrm{t}-1}\right)$

Independen Variabel: Order Flow periode $\mathrm{t}-2\left(\mathrm{Q}_{\mathrm{t}-2}\right)$

Metode: Least Square

Sampel : 1.782 


\begin{tabular}{|c|c|c|c|}
\hline \multicolumn{4}{|c|}{ Model: $\mathrm{Q}_{\mathrm{t}-1}=(1-2 \pi) \mathrm{Q}_{\mathrm{t}-2}+\xi_{\mathrm{t}}$} \\
\hline \multirow[b]{2}{*}{ Model } & \multicolumn{2}{|c|}{ Unstandarized Coefficients } & Standarized Coefficients \\
\hline & B & Std.Error & Beta \\
\hline $\begin{array}{l}\text { Konstanta } \\
\mathrm{Q}_{\mathrm{t}-2}\end{array}$ & $\begin{array}{r}0,020 \\
-0,021\end{array}$ & $\begin{array}{l}0,022 \\
0,024\end{array}$ & $-0,021$ \\
\hline
\end{tabular}

Sumber: Hasil Olahan Data Penelitian dengan Mempergunakan SPSS Version 15.

Berdasarkan Tabel 2, dapat dikemukakan bahwa koefisien indikator order flow saham pada periode $\mathrm{t}-2$ sebesar - 0,021. Artinya, kemungkinan arah order flow pada periode $\mathrm{t}-2$ memiliki arah yang berlawanan dengan arah order flow pada periode $t-1$ sebesar 51,05 persen.

Ketiga, menentukan komponen adverse selection cost. Dengan mempergunakan hasil estimasi koefisien $\mathrm{Q}_{\mathrm{t}-2}$ pada Tabel 2 sebagai input dalam menentukan adverse selection cost, maka rekapitulasi hasil penelitian komponen adverse selection cost dapat dilihat pada Tabel 3 berikut ini.

Tabel 3. Rekapitulasi Hasil Penelitian Komponen Adverse Selection Cost

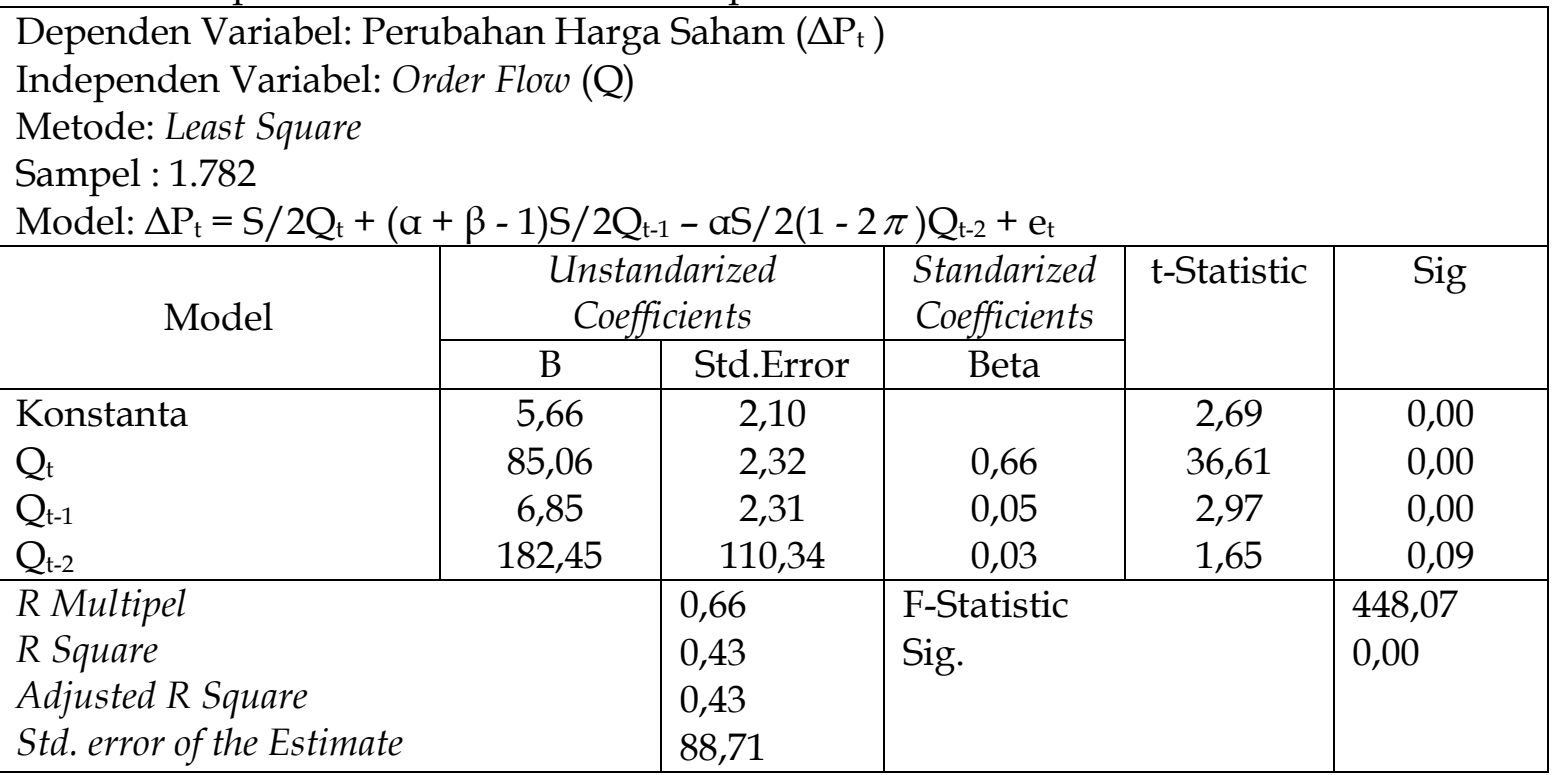

Sumber: Hasil Olahan Data Penelitian dengan Mempergunakan SPSS Version 15.

Berdasarkan Tabel 3 dapat dikemukakan bahwa nilai adverse selection cost sebesar 0,03 dan signifikan secara statistik dengan nilai t-hitung adalah 1,65 (probabilitas sebesar 0,09). Dengan demikian, nilai inventory holding cost adalah 0,68. Selanjutnya, nilai $R$-Square sebesar 0,43 dengan nilai F-hitung sebesar 448,07 (probabilitas sebesar 0,000). Kondisi ini menunjukkan bahwa model yang dibangun relatif cukup baik.

Keempat, menentukan dekomposisi masing-masing komponen traded spread. Dengan mengacu pada besaran koefisien-koefisien regressi yang terdapat pada Tabel 1 dan 3 dapat dikemukakan bahwa besaran traded spread saham selama periode pengamatan tahun 2007 2008 adalah 0,94. Proporsi traded spread yang bersumber dari order processing cost sebesar 29 persen dari traded spread, inventory holding cost sebesar 68 persen dari traded spread, dan adverse selection cost sebesar 3 persen dari traded spread. 
Traded spread di Bursa Efek Indonesia relatif lebih besar bila dibandingkan dengan traded spread di beberapa bursa lain, seperti NYSE. Hasil penelitian yang dilakukan oleh Huang dan Stoll (1997) menunjukkan bahwa traded spread sebesar 0,1222. Traded spread saham di Bursa Efek Indonesia 8 kali lebih besar dari traded spread saham di NYSE. Kondisi ini menggambarkan bahwa biaya transaksi dalam melakukan aktivitas perdagangan saham di Bursa efek Indonesia lebih mahal bila dibandingkan dengan biaya transaksi saham di NYSE. Oleh karenanya, hasil penelitian ini dapat dipergunakan pengelola bursa sebagai dasar dalam penentuan kebijakan untuk meningkatkan kinerja bursa saham. Kebijakan yang dilakukan adalah kebijakan yang dapat menurunkan biaya transaksi saham, yaitu: melalui mekanisme perdagangan saham yang lebih baik maupun peningkatan transparansi.

Lebih lanjut, dengan mengelompokkan komponen traded spread menjadi real friction dan information friction, hasil penelitian menunjukkan bahwa komponen real friction sebesar 97 persen dari traded spread dan komponen information friction sebesar 3 persen dari traded spread. Artinya, komponen real friction mendominasi traded spread. Oleh karenanya, hasil penelitian ini sesuai dengan hasil penelitian yang dilakukan oleh para peneliti lain di pasar saham yang sudah maju. Hasil penelitian yang dilakukan oleh George et al. (1991) menunjukkan bahwa adverse selection cost sekitar 8 - 13 persen dari quoted spread dan real friction sekitar 87-92 persen dari quoted spread. Huang dan Stoll (1997) menunjukkan bahwa information friction adalah 9,6 persen dan real friction adalah 90,4 persen dari traded spread. Madhavan et al. (1997) menunjukkan bahwa adverse selection cost sebesar 0,034 cents dan real friction adalah 0,196 cents per \$ 100. Heflin et al. (2000) menunjukkan bahwa adverse selection cost adalah 5,6 cents dan real friction adalah 9,6 cents per share. Stoll (2000) menunjukkan bahwa real friction dan information friction masing-masing adalah 3,7 dan 2 cents pada NYSE/AMEX serta real dan information friction masing-masing adalah 8 dan 2,5 cents per \$ 100 pada NASDAQ. Selanjutnya, hasil penelitian yang dilakukan oleh Hanousek dan Podpiera (2002) menunjukkan bahwa kontribusi adverse selection cost terhadap spread lebih rendah bila dibandingkan dengan kontribusi inventory holding cost terhadap spread.

Dekomposisi traded spread saham di Bursa Efek Indonesia didominasi oleh komponen inventory holding cost. Kondisi ini menggambarkan bahwa aktivitas perdagangan saham didominasi oleh para perantara dalam memenuhi kebutuhan portofolionya (rebalancing portfolio). Dengan aktifnya perantara dalam memenuhi kebutuhan portofolionya mengakibatkan saham-saham yang diperdagangkan di Bursa Efek Indonesia semakin sering dianalisis dan dengan demikian perantara berperan dalam menurunkan informasi asimetris antara informed traders dengan uninformed traders. Oleh karenanya, kontribusi adverse selection cost terhadap traded spread di Bursa Efek Indonesia relatif lebih rendah bila dibandingkan dengan kontribusi order processing cost dan inventory holding cost.

Disamping hal tersebut, relatif rendahnya kontribusi komponen adverse selection cost terhadap traded spread mengindikasikan bahwa tingkat disclosure di Bursa Efek Indonesia relatif cukup baik. Oleh karenanya, hal yang perlu dilakukan pengelola bursa dalam meningkatkan kinerja pasar saham adalah mempertahankan tingkat transparansi yang sudah berlangsung selama ini dan meningkatkan kualitas mekanisme perdagangan saham.

Untuk mendapatkan informasi lain, model juga diimplementasikan berdasarkan tahun pengamatan. Rekapitulasi hasil penelitian traded spread, jumlah komponen inventory holding cost dan adverse selection cost tahun 2007 dapat dilihat pada Tabel 4 berikut ini.

Tabel 4. Rekapitulasi Hasil Penelitian Traded Spread, Jumlah Komponen Inventory Holding Cost dan Adverse Selection Cost Tahun 2007

Dependen Variabel: Perubahan Harga Saham $\left(\Delta \mathrm{P}_{\mathrm{t}}\right)$ 


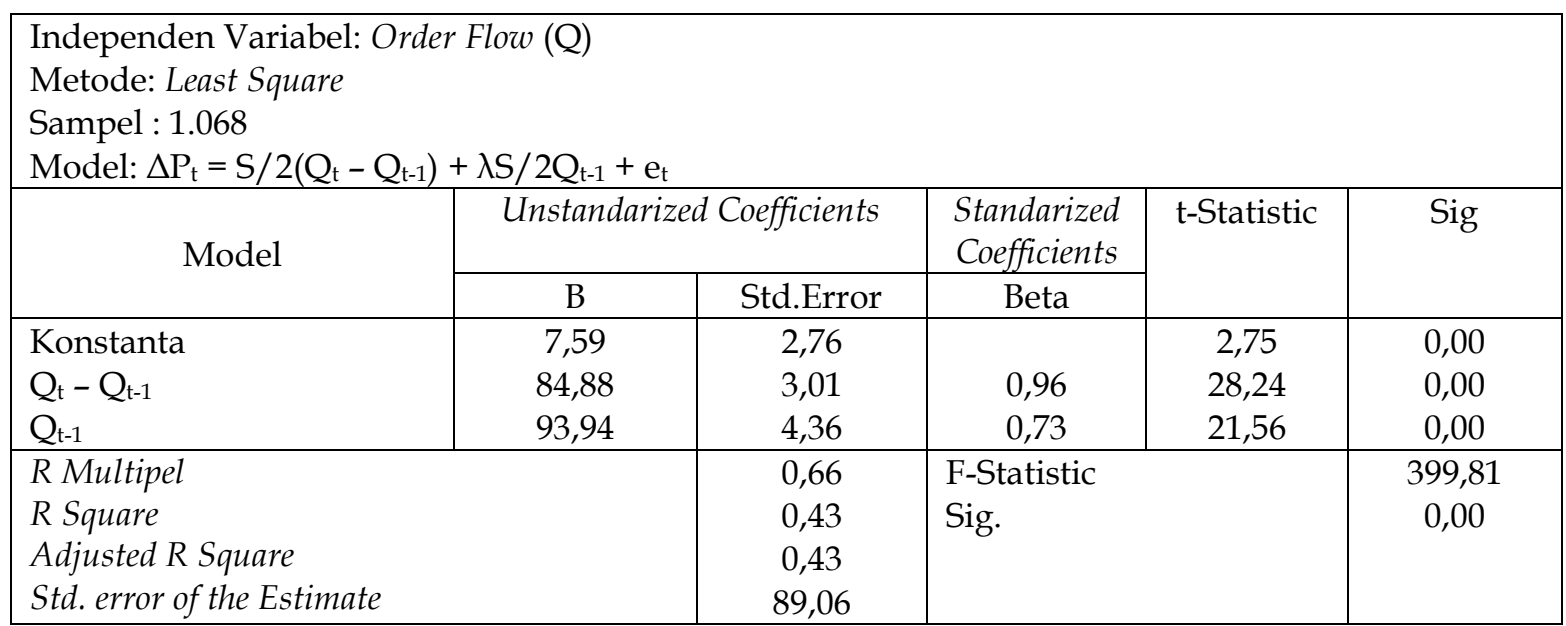

Sumber: Hasil Olahan Data Penelitian dengan Mempergunakan SPSS Version 15.

Berdasarkan Tabel 4 di atas dapat dikemukakan bahwa nilai traded spread saham di Bursa Efek Indonesia adalah 0,96 dan signifikan secara statistik dengan nilai t-hitung adalah 28,24 (probabilitas sebesar 0,00). Selanjutnya, koefisien jumlah inventory holding cost dan adverse selection cost sebesar 0,73 dan signifikan secara statistik dengan nilai t-hitung adalah 21,56 (probabilitas sebesar 0,00). Dengan mempergunakan besaran koefisien jumlah inventory holding cost dan adverse selection cost, maka besaran order processing cost ditentukan dengan mempergunakan formula $1-\lambda$. Oleh karenanya, secara rata-rata besaran order processing cost adalah 0,26.

Berdasarkan pengamatan terhadap hubungan order flow periode $\mathrm{t}-2$ dan order flow periode $\mathrm{t}$ - 1 yang dipergunakan sebagai input dalam menentukan besaran adverse selection cost, maka rekapitulasi hasil penelitian komponen adverse selection cost tahun 2007 dapat dilihat pada Tabel 5 berikut ini.

Tabel 5. Rekapitulasi Hasil Penelitian Komponen Adverse Selection Cost Tahun 2007

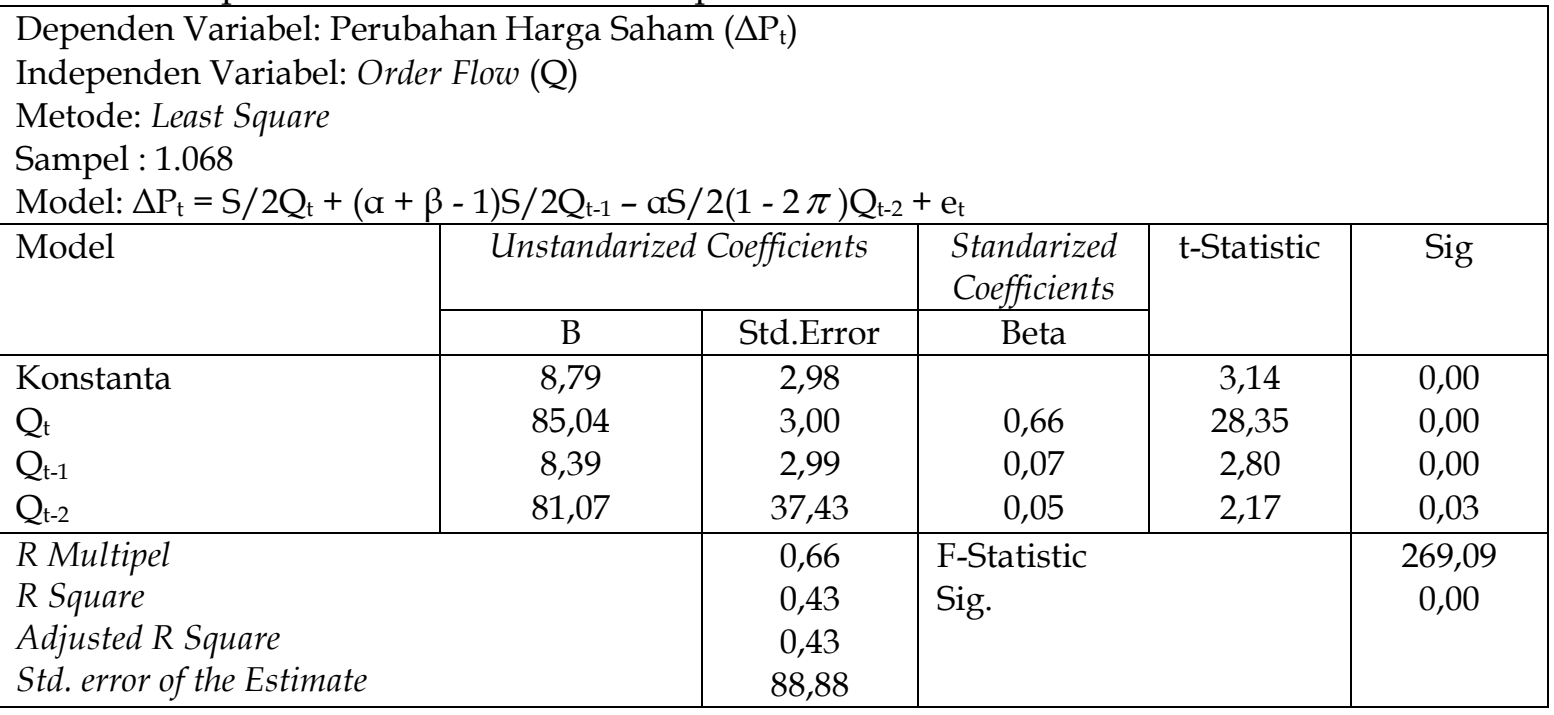

Sumber: Hasil Olahan Data Penelitian dengan Mempergunakan SPSS Version 15.

Berdasarkan Tabel 5 dapat dikemukakan bahwa nilai adverse selection cost sebesar 0,05 dan signifikan secara statistik dengan nilai t-hitung adalah 2,17 (probabilitas sebesar 0,03). Dengan demikian, nilai inventory holding cost adalah 0,68. Selanjutnya, nilai $R$-Square sebesar 0,43 dengan nilai F-hitung sebesar 269,09 (probabilitas sebesar 0,000). Kondisi ini menunjukkan bahwa model yang dibangun relatif cukup baik. 
Dengan mengacu pada besaran koefisien-koefisien regressi yang terdapat pada Tabel 4 dan 5 dapat dikemukakan bahwa besaran traded spread saham tahun 2007 adalah 0,96. Proporsi traded spread yang bersumber dari order processing cost sebesar 26 persen dari traded spread, inventory holding cost sebesar 68 persen dari traded spread, dan adverse selection cost sebesar 5 persen dari traded spread. Lebih lanjut, kontribusi real friction terhadap traded spread adalah 94 persen dan kontribusi information friction adalah 5 persen.

Di samping diimplementasikan pada tahun 2007, model juga diimplementasikan untuk tahun 2008. Rekapitulasi hasil penelitian traded spread, jumlah komponen inventory holding cost dan adverse selection cost tahun 2008 dapat dilihat pada Tabel 6 berikut ini.

Tabel 6. Hasil Penelitian Traded Spread, Jumlah Komponen Inventory Holding Cost dan Adverse Selection Cost tahun 2008

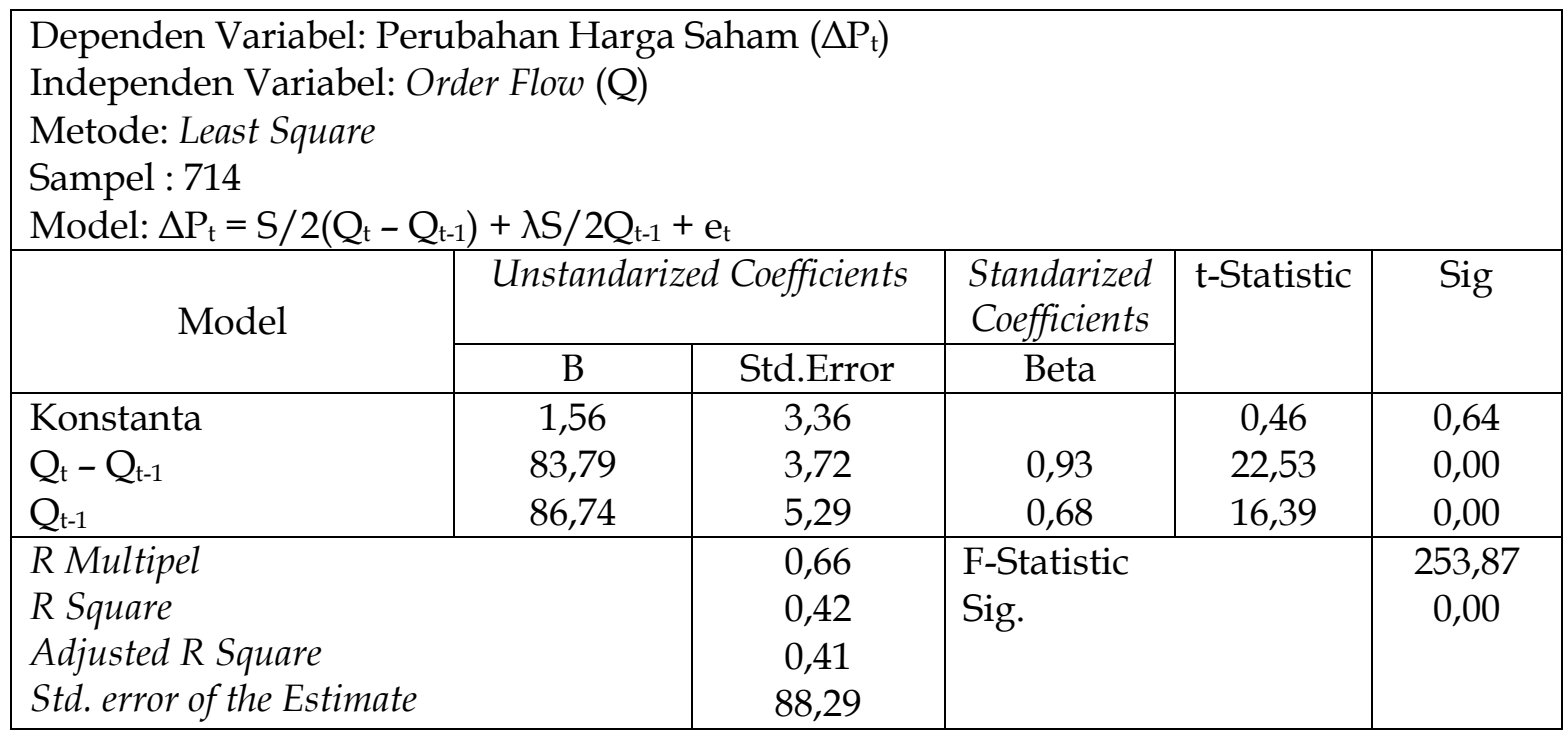

Sumber: Hasil Olahan Data Penelitian dengan Mempergunakan SPSS Version 15.

Berdasarkan Tabel 6 di atas dapat dikemukakan bahwa nilai traded spread saham adalah 0,93 dan signifikan secara statistik dengan nilai t-hitung adalah 22,53 (probabilitas sebesar 0,00). Selanjutnya, koefisien jumlah inventory holding cost dan adverse selection cost sebesar 0,68 dan signifikan secara statistik dengan nilai t-hitung adalah 16,39 (probabilitas sebesar 0,00). Dengan mempergunakan besaran koefisien jumlah inventory holding cost dan adverse selection cost, maka besaran order processing cost ditentukan dengan mempergunakan formula $1-\lambda$. Oleh karenanya, secara rata-rata besaran order processing cost adalah 0,32.

Berdasarkan pengamatan terhadap hubungan order flow periode $t-2$ dan order flow periode $\mathrm{t}-1$ yang dipergunakan sebagai input dalam menentukan adverse selection cost, maka rekapitulasi hasil penelitian komponen adverse selection cost tahun 2008 dapat dilihat pada Tabel 7 berikut ini. 
Tabel 7. Rekapitulasi Hasil Penelitian Komponen Adverse Selection Cost

Tahun 2008

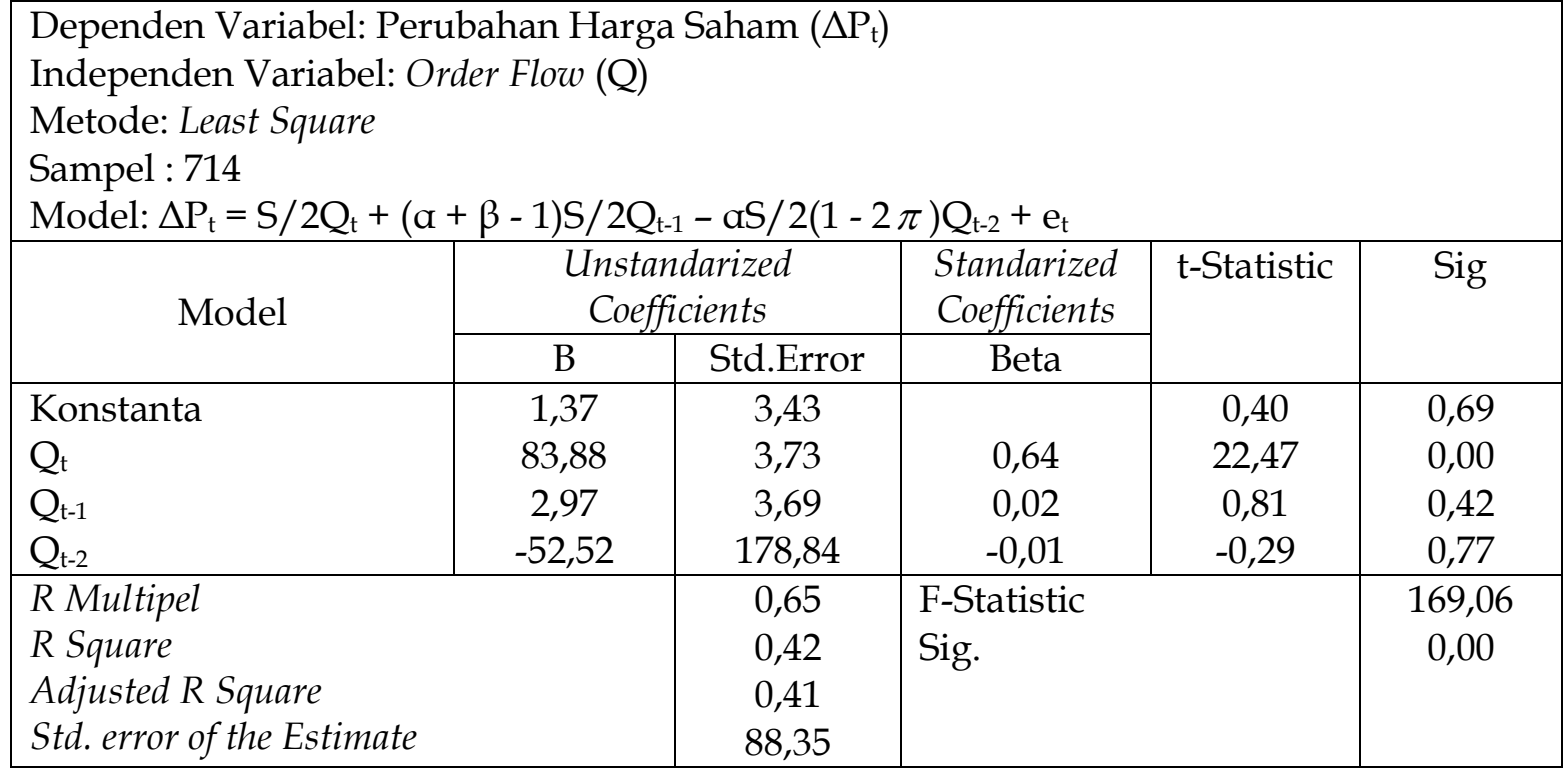

Sumber: Hasil Olahan Data Penelitian dengan Mempergunakan SPSS Version 15.

Berdasarkan Tabel 7 dapat dikemukakan bahwa nilai adverse selection cost sebesar - 0,01 dan tidak signifikan secara statistik dengan nilai t-hitung adalah -0,29 (probabilitas sebesar 0,77). Nilai koefisien adverse selection cost relatif rendah dan tidak signifikan secara statistik menggambarkan bahwa order flow pada tahun 2008 didominasi oleh uninformed traders sehingga menurunkan probabilitas bahwa market maker melakukan transaksi dengan informed traders. Selanjutnya, nilai koefisien determinan adalah 0,42 dan signifikan secara statistik dengan nilai F-hitung sebesar 169,06 (probabiltas sebesar 0,00).

Dengan mengacu pada besaran koefisien-koefisien regressi yang terdapat pada Tabel 6 dan 7 dapat dikemukakan bahwa besaran traded spread saham tahun 2008 adalah 0,93. Proporsi traded spread yang bersumber dari order processing cost sebesar 32 persen dari traded spread, inventory holding cost sebesar 69 persen dari traded spread, dan adverse selection cost sebesar -1 persen dari traded spread.

Menurut Glosten dan Milgrom (1985), besaran adverse selection cost selalu ada yang walaupun order processing cost dan inventory holding cost tidak ada. Artinya, besaran adverse selection cost selalu positip. Dengan mengacu pada pendapat tersebut serta membandingkannya dengan hasil penelitian, nilai adverse selection cost pada tahun 2008 negatip disebabkan: Pertama, dealer secara rata-rata mengkonsumsi likuiditas untuk mengurangi dampak informasi tidak simetris. Kondisi ini terlihat dari kontribusi inventory holding cost terhadap traded spread relatif lebih besar dibandingkan dengan kontribusi komponen traded spread lainnya. Kedua, walaupun secara teori bahwa biaya transaksi bernilai positip dalam single dealer environment sebagai kompensasi untuk menyediakan likuiditas, batasan ini tidak sepenuhnya dapat diterima pada quote driven market. Ketiga, dalam lingkungan penilaian yang heterogen, dealer memiliki kemampuan untuk menjual kepada dealer yang lebih optimistik dan membeli dari dealer yang lebih pesimistik akan efektif menurunkan biaya transaksi. Oleh karena ketiga hal tersebut, maka adverse selection cost pada tahun 2008 bernilai negatip.

Dengan membandingkan traded spread dan dekomposisi traded spread saham tahun 2007 dan 2008 dapat dikemukakan bahwa traded spread saham mengalami penurunan sebesar 3,13 persen menjadi 0,93 tahun 2008 dari 0,96 tahun 2007. Penurunan traded spread diikuti dengan 
penurunan adverse selection cost. Kondisi ini menggambarkan meningkatnya kinerja pasar saham pada tahun 2008. Lebih lanjut, dengan membandingkan order processing cost tahun 2007 dan tahun 2008, maka model yang dibangun cukup baik. Hal ini disebabkan besaran order processing cost relatif sama. Selain hal tersebut, dengan memperhatikan besaran koefisien determinan jika semua data dipergunakan dan jika data dikelompokkan berdasarkan tahun pengamatan, nilai koefisien determinasi relatif sama dengan nilai koefisien determinan berada dalam kisaran $42-43$ persen.

Traded spread atau biaya transaksi merupakan informasi yang perlu diperhatikan Badan Pengawas Pasar Modal (Bapepam)-Lembaga Keuangan sebagai pihak yang bertugas dan berwenang melakukan pengawasan dan pengembangan pasar saham. Pengembangan regulasi pasar merupakan suatu cara untuk mendorong pasar berfungsi dengan baik. Oleh karena itu, mekanisme perdagangan dan transparansi merupakan aspek yang perlu diperhatikan untuk mendorong pasar berfungsi dengan baik, sebab melalui mekanisme perdagangan dan transparansi yang semakin baik, biaya transaksi semakin murah. Selanjutnya, pengelola bursa sebagai selft regulatory dapat mempergunakan informasi komponen biaya transaksi dalam mengadopsi kebijakan. Hasil penelitian menunjukkan bahwa non information cost mendominasi traded spread saham di Bursa Efek Indonesia. Oleh karenanya, perlu dipertahankan tingkat transparansi yang terjadi selama ini dan perlu ditingkatkan kualitas mekanisme perdagangan saham.

\section{KESIMPULAN DAN SARAN}

Berdasarkan hasil dan pembahasan, dapat ditarik beberapa kesimpulan sebagai berikut:

Pertama, order processing cost, inventory holding cost, dan adverse selection cost merupakan komponen traded spread saham.

Kedua, traded spread saham sebesar 0,94 dan signifikan secara statistik dengan probabilitas adalah 0,00. Jumlah inventory holding cost dan adverse selection cost sebesar 0,71 dan signifikan secara statistik dengan probabilitas adalah 0,00 , serta nilai adverse selection cost sebesar 0,03 dan signifikan secara statistik dengan probabilitas adalah 0,09.

Ketiga, kontribusi order processing cost terhadap traded spread sebesar 29 persen, kontribusi inventory holding cost terhadap traded spread sebesar 68 persen dan kontribusi adverse selection cost terhadap traded spread sebesar 3 persen.

Keempat, kontribusi real friction sebesar 97 persen dan kontribusi information friction sebesar 3 persen terhadap traded spread.

Kelima, Koefisien determinan sebesar 43 persen dan signifikan secara statistik dengan probabilitas sebesar 0,00

Ketujuh, kinerja pasar saham mengalami peningkatan yang ditunjukkan oleh penurunan traded spread sebesar 3,13 persen dan penurunan adverse selection cost sebesar 120 persen.

Mengacu pada kesimpulan tersebut, maka penting ditingkatkan kinerja pasar saham. Kinerja pasar saham dapat ditingkatkan dengan mempertahankan atau meningkatkan transparansi pengungkapan informasi aktivitas perdagangan serta meningkatkan kualitas mekanisme perdagangan saham. 


\section{DAFTAR PUSTAKA}

Ellis, K., R. Michaely and M. O'Hara, 2000, The Accuracy of Trade Classification Rules: Evidence from NASDAQ, Journal of Financial and Quantitative Analysis 35, 529 - 551.

Fuss, Roland, 2002, The Financial Characteristics between Emerging and Developed Equity Markets, Institute for General Economic Research, Department of Empirical Economic Research and Econometrics, Albert-Ludwigs-University Freiburg.

George, Thomas J., Gautam Kaul and M. Nimalendran, 1991, Estimation of the Bid-Ask Spread and Its Components: A New Approach, Review of Financial Studies 4, 623 - 656.

Glosten, L., and L. Harris, 1988, Estimating the Component of the Bid/ask Spread, Journal of Financial Economics 21, 123 - 142.

Glosten, Lawrence and Paul Milgrom, 1985, Bid, Ask and Transaction Prices in a Specialist Market with Heterogeneously Informed Traders", Journal of Financial Economics 14, 71 100.

Hanousek, Jan and Richard Podpiera, 2002, Informed Trading and Bid-ask Spread: Evidence from an Emerging Market, Working paper, CERGE-EI, Czech Republic.

Hasbrouck, J. and D. Seppi, 2001, Common Factors in Prices, Order Flows, and Liquidity, Journal of Financial Economics 59, 383-411.

Heflin, Frank., Kenneth W. Shaw and John J. Wild, 2000, Disclosure Quality and Market Liquidity, Working paper, Purdue University.

Huang, R., dan H. Stoll, 1997, The Component of the Bid-ask Spread: A General Approach, Review of Financial Studies 10, 995 - 1034.

Institute for Economic and Financial Research, 2008, Indonesian Capital Market Directory.

Madhavan, A., M. Richardson, dan M. Roomans, 1997, Why Do Securities Prices Change ? A Transaction Level Analysis of NYSE-Listed Stocks, Review of Financial Studies 10, 1035 1064.

Roll, Richard, 1984, A Simple Implicit Measure of the Effective Bid-ask Spread in Efficient Market, Journal of Finance 39, 1127 - 1139.

Stoll, H. R., 2000, Friction, Journal of Finance 55, 1479 - 1514.

Stoll, Hans R., 1989, Inferring the Components of the Bid-ask Spread: Theory and Empirical Tests, Jounal of finance 44, 115 - 134. 